\title{
Integrated approach for effective bioethanol production using whole slurry from autohydrolyzed Eucalyptus globulus wood at high-solid loadings
}

\author{
Aloia Romaní ${ }^{a}$, Héctor A. Ruiz ${ }^{b}$, Francisco B. Pereira ${ }^{a}$, José A. Teixeira ${ }^{a}$, Lucília Domingues ${ }^{\mathrm{a}, *}$ \\ ${ }^{a}$ CEB-Centre of Biological Engineering, University of Minho, Campus Gualtar, 4710-057 Braga, Portugal \\ ${ }^{\mathrm{b}}$ Biorefinery Group, Food Research Deparment/School of Chemistry, Autonomous University of Coahuila, Blvd. V. Carranza e Ing. José Cárdenas Valdés, \\ 25280 Saltillo, Coahuila, Mexico
}

\section{H I G H L I G H T S}

- Integrated process optimization was evaluated for 2G bioethanol production.

- Enzymatic saccharification of whole-slurry from pretreatment was optimized.

- Two strategies with/without presaccharification to ethanol production were compared.

- Optimized conditions lead ethanol titer $>6 \%$ using industrial yeast strain by SSF.

- Effective bioethanol production from whole slurry E. globulus was achieved.

\section{A R T I C L E I N F O}

\section{Article history:}

Received 20 March 2014

Received in revised form 29 May 2014

Accepted 25 June 2014

Available online 21 July 2014

\section{Keywords:}

Eucalyptus globulus wood

Autohydrolysis pretreatment

Whole-slurry

High-solid loadings

Bioethanol

\begin{abstract}
A B S T R A C T
One of the most important targets and challenges in the second generation bioethanol is the development of a cost-effective process on large-scale. In this context, the high solid loading on saccharification and fermentation and the use of whole-slurry from pretreatment could be promising alternatives to obtain high ethanol concentrations and to decrease operational costs and wastewater. In this work, Eucalyptus globulus wood was submitted to non-isothermal autohydrolysis treatment $\left(T_{\max }=210^{\circ} \mathrm{C}\right)$ and the whole-slurry obtained was assayed for the optimization of enzymatic saccharification at different solid and enzymes (CTec2 and $\mathrm{HTec} 2$ ) loadings using a Box-Behnken experimental design. Under the optimized conditions (liquid solid ratio $6.4 \mathrm{~g} / \mathrm{g}$, cellulase to substrate ratio $22.5 \mathrm{FPU} / \mathrm{g}$ and hemicellulase to substrate ratio $500 \mathrm{UI} / \mathrm{g}$ ), two strategies were evaluated for ethanol production (Simultaneous Saccharification and Fermentation, SSF and Presaccharification and Simultaneous Saccharification and Fermentation, PSSF), using an industrial and robust Saccharomyces cerevisiae strain. High concentrations of ethanol $(50.2$ and $48.8 \mathrm{~g} / \mathrm{L})$ and productivities $(0.63$ and $0.55 \mathrm{~g} / \mathrm{L} \mathrm{h})$ were obtained by SSF and PSSF, respectively. The SSF process proved to be an advantageous strategy to obtain concentrations $>6 \%$ (v/v) of ethanol with elevated conversion (95\%) even employing high solid loading and non-detoxified hydrolysate. Following an integrated optimization process, cost-effective bioethanol production conditions from whole-slurry $E$. globulus wood were determined and validated experimentally, representing a step-forward towards its industrial implementation.
\end{abstract}

(c) 2014 Elsevier Ltd. All rights reserved.

\section{Introduction}

The abundant amount of biomass and its availability allow its processing, which could become a commercial opportunity. Lignocellulosic materials (LCMs), as Eucalyptus globulus wood (EGW), represent a renewable and widespread biomass source that does

\footnotetext{
* Corresponding author.

E-mail address: luciliad@deb.uminho.pt (L. Domingues).
}

not compete with crops used in feed (such amylaceous materials and sugar biomass). The biorefinery approach consists in the fractionation of lignocellulose biomass as alternative to petroleum refinery $[1,2]$ and its sustainable development allows the possibility to obtain commercial products such as chemical products, materials, energy and fuels [3].

The processing or pretreatment of LCMs is considered as first step in a biorefinery [4,5], being the main barrier its recalcitrant complex structure that is formed by its three main components 
(hemicellulose, lignin and cellulose). A wide number of technologies have been proposed for fractionation of LCMs in aqueous alkali and acid media, or mechanical pretreatments to improve the enzymatic accessibility [6-8]. In this context, hydrothermal treatment or alternative also known autohydrolysis or liquid hot compressed water is a possible pretreatment to biomass processing that yields a liquid phase (hydrolysate) composed by hemicellulose derivedcompounds (mainly oligosaccharides and monosaccharides) and solid phase enriched in cellulose and lignin [9].

The bioethanol is one of the most important liquid fuels obtained from the processing of LCM [10]. In this context, the Policy Energy Act (PEA) and the Energy Independence and Security Act (EISA) have agreed to reach 36 billion gallons of bioethanol in 2022 [11]. However, bioethanol from LCM is not widely implemented on large-scale due to the high initial investment and high production operational costs. One alternative to reduce capital-operational cost can be to use the whole-slurry (liquid + solid) or slurries after treatment without washing (avoiding water consumption) and/or operating with high solid loadings (to obtain elevated final ethanol concentration and so decrease the distillation cost) $[12,13]$. Besides, the incorporation of hydrolysate is preferable since it increases the sugar concentration availability for yeast subsequent fermentation [14].

Nevertheless, some soluble derived compounds of pretreatment (weak acids, furan and phenolic compounds) present in the wholeslurry are effective inhibitory compounds of the saccharification and fermentation processes $[15,16]$. Taking into account that detoxification step of liquid phase is not desirable due to the high cost (that can represent up to $22 \%$ of total cost of production of bioethanol) [17], one alternative to physic-chemical methods of detoxification could be the biological treatments. Biological detoxification involves the use of enzymes and microorganism that are able to act on the toxic compounds present in the hydrolysate [18].

The cellulolytic enzymes are inhibited by compounds released during the pretreatment (mainly phenolics compounds and oligosaccharides) $[19,20]$, indicating the need of robust enzymes able to maintain their activity in presence of these compounds [21]. In this sense, several researches have recently been carried out on improving the properties of Trichoderma reesei cellulases [22,23]. Moreover, the use of cocktail hemicellulases can improve the saccharification since it acts on hemicellulose enhancing the cellulose accessibility [24].

On the other hand, the furan (furfural and hydroxymethyl furfural) and phenolic compounds clearly affect the growth and metabolism of yeast $[25,26]$. Thus, one of the major advances in bioethanol production could be the selection of robust microorganism able to ferment sugars in presence of inhibitor compounds and attain high ethanol titers at the end of fermentation process [27]. A recent published work showed that the industrial distillery environments as "Brazilian bioethanol plants" are a remarkable source of efficient yeast strains for lignocellulosic fermentation processes, able to degrade furans compounds and obtain an efficient ethanol performance [28].

Regarding strategies of operation, the bioethanol production can be performed using separate hydrolysis and fermentation (SHF), and Simultaneous Saccharification and Fermentation (SSF) or to conduct a Pre-saccharification followed by Simultaneous Saccharification and Fermentation (PSSF) [29]. In this context, the study of all involved stages in the bioethanol production (including: the operational conditions of LCM fractionation, the use of robust enzymes and yeast able to remain their activity in presence of inhibitors) is the main objective to obtain a sustainable and integrated process.

This work studies the use of whole-slurry from autohydrolyzed E. globulus wood in order to obtain high concentration and conversion of glucose in the enzymatic saccharification assay using novel cellulolytic enzymes (CTec2 and HTec2). In the optimized conditions of enzymatic hydrolysis, PSSF and SSF experiments were carried out to evaluate the maximum ethanol yields obtained by a robust industrial strain of Saccharomyces cerevisiae.

\section{Materials and methods}

\subsection{Raw material}

E. globulus wood (EGW) was kindly provided by ENCE (local pulp factory; Galicia NW Spain). The samples were air-dried, homogenized and milled to pass an $8 \mathrm{~mm}$ screen. Finally, the lot was stored in a dark and dry place until use. The EGW composition was previously analyzed by Pereira et al. [28], containing (expressed in $\mathrm{g} / 100 \mathrm{~g}$ of raw material on dry basis, average values of three replicate \pm standard deviation): glucan $44.70 \% \pm 0.81$; xylan 16.01\% \pm 0.35 ; arabinan $1.09 \pm 0.05$; acetyl groups $2.96 \% \pm 0.28$; Klason lignin $27.70 \% \pm 0.61$; ashes $0.2 \% \pm 0.03$ and extractives $2 \% \pm 0.17$.

\subsection{Pretreatment: autohydrolysis}

EGW was submitted to autohydrolysis pretreatment. EGW and distilled water were mixed in a Liquid to Solid Ratio (LSR) $=8 \mathrm{~kg}$ of water $/ \mathrm{kg}$ of oven-dried raw material in a pressurized reactor at $T_{\max }=210^{\circ} \mathrm{C}$ (non-isothermal regime). The reaction media was heated and cooled following the standard temperature profiles reported by Romaní et al. [30]. When the treatment was finished the solid was recovered for solid yield determination (SY) and separated of hydrolysate by filtration. The liquid and solid phases were analyzed for chemical composition (as described below) and listed in Table 1.

\subsection{Enzymes}

The enzymes employed in this work, cellulases (Cellic Ctec2) and hemicellulases (Cellic Htec2) were kindly supplied by Novozymes, (Bagsvaerd, Denmark). The Celluclast 1.5 and Novozyme 188 were also used for comparative reason. The Cellic CTec2 was used for saccharification of cellulose into glucose. The $\beta$-glucosidase enzyme supplementation was not necessary due to the high activity of $\beta$-glucosidase present in Cellic CTec2. The hemicellulase enzyme Cellic HTec2 was added to hydrolyse the xylooligosaccharides and improve the cellulose saccharification. The cellulase

Table 1

Chemical composition of pretreated solid and hydrolysate.

\begin{tabular}{lc} 
g Of compound/100 g of raw material oven dry basis & \\
Solid Yield (SY) & 71.66 \\
Pretreated solid & \\
Glucan & $42.47 \pm 0.47$ \\
Xylan & $1.40 \pm 0.10$ \\
Arabinan & $0.0 \pm 0.00$ \\
Acetyl groups & $0.21 \pm 0.06$ \\
Klason lignin & $24.08 \pm 0.50$ \\
Hydrolysate g of compound/100 g of raw material oven & dry basis \\
Glucose & $0.53 \pm 0.05$ \\
Xylose & $7.33 \pm 0.15$ \\
Arabinose & $0.15 \pm 0.03$ \\
Acetic acid & $2.58 \pm 0.07$ \\
HMF & $0.27 \pm 0.01$ \\
Furfural & $1.38 \pm 0.12$ \\
Glucooligosaccharides & $0.95 \pm 0.24$ \\
Xylooligosaccharides & $7.43 \pm 0.74$ \\
Arabinooligosaccharides & $0.00 \pm 0.0$ \\
Acetyl groups & $2.11 \pm 0.35$ \\
\hline
\end{tabular}


activity of Cellic Ctec2 was measured by the Filter Paper assay [31] and was expressed as Filter Paper Unit (FPU). The $\beta$-glucosidase activity of Ctec2 was determined as International Unit (IU), using $\rho$-nitrophenyl- $\beta$-D-glucopyranoside as substrate [32]. The xylanase activity of Cellic Htec 2 was assayed as described in Bailey et al. [33], using birchwood xylan. The activities were $120 \pm 10 \mathrm{FPU} / \mathrm{mL}$ and $779.8 \pm 20.3 \mathrm{UI} / \mathrm{mL}$ for $\mathrm{CTec} 2$ and $1690 \pm 211.6 \mathrm{UI} / \mathrm{mL}$ for HTec2.

\subsection{Enzymatic hydrolysis of whole slurry: experimental plan and statistical analysis}

A Box-Behnken, second-order design based on the three-level incomplete factorial designs, experimental plan was carried out ( 3 factors with three replicates of the central point, total experiments 15) for the optimization of whole-slurry saccharification (liquid + solid). The number of experiments $(N)$ was calculated as follows [34]:

$N=k^{2}+k+c_{\mathrm{p}}$

where $k$ is the factor number $(k=3)$ and $c_{\mathrm{p}}$ is the replica number of the central point.

The structure of the experimental plan is summarized in Table 2. The independent variables were: Liquid to Solid Ratio (LSR) $=x_{1}$, Cellulase to Substrate Ratio (CSR) $=x_{2}$ and Hemicellulase to Substrate Ratio $(\mathrm{HSR})=x_{3}$. The substrate of variable $x_{2}$ is referred to pretreated solid and the substrate of $x_{3}$ is corresponded with the concentration of xylooligosaccharides in the hydrolysate. The dimensionless ones of independent variables were calculated (with variation range from -1 to 1 ) following the equation:

$x_{1}=2 \cdot \frac{\mathrm{LSR}_{i}-\mathrm{LSR}_{\text {mean }}}{\mathrm{LSR}_{\text {max }}-\mathrm{LSR}_{\text {min }}}$

$x_{2}=2 \cdot \frac{\mathrm{CSR}_{i}-\mathrm{CSR}_{\text {mean }}}{\mathrm{CSR}_{\max }-\mathrm{CSR}_{\min }}$

$x_{3}=2 \cdot \frac{\mathrm{HSR}_{i}-\mathrm{HSR}_{\text {mean }}}{\mathrm{HSR}_{\text {max }}-\mathrm{HSR}_{\text {min }}}$

where the subscripts $i$ is the considered experiment, mean is the average value of the variable min and max and min and max mean minimum and maximum values of the respective variation ranges, respectively.
The independent variables were correlated with dependent variables by a second-polynomial equation following the generalized expression:

$y_{j}=b_{0 j}+\sum_{i=1}^{2} b_{i j} x_{i}+\sum_{i=1}^{2} \sum_{k \geqslant i}^{2} b_{i k j} x_{i} x_{k}$

where $y_{j}(j=1$ to 4$)$ is the dependent variable; $x_{i}$ or $x_{k}(i$ or $k: 1$ to 3 , $k \geqslant i)$ are the normalized, independent variables (defined in Table 2), and $b_{0 j} \ldots b_{i k j}$ are regression coefficients calculated from experimental data by multiple regression using the least-squares method. The experimental data were fitted to the proposed models using commercial software (Statgraphics, Plus 5.1, Warrenton, VA, USA). The regression coefficients $\left(b_{0 j} \ldots b_{i k j}\right)$ of experimental, the significance (based on the Student's $t$-test), the correlation coefficient $\left(R^{2}\right)$ and the significance of model design (based on the Fisher's Ftest) are shown in Table 3.

The enzymatic hydrolysis assays were carried out in a $100 \mathrm{~mL}$ Erlenmeyer flasks ( $50 \mathrm{~mL}$ of medium) at $48.5^{\circ} \mathrm{C}$ and $\mathrm{pH}=4.85$ ( $0.05 \mathrm{~N}$ citric acid-sodium citrate buffer) in an orbital shaker (150 rpm). The assays were prepared with pretreated solid, hydrolysate and enzymes at desired amounts (see Table 2). Representative samples were withdrawn (approximately, a volume of $0.8 \mathrm{~mL}$ ) from experiments at times $0,2,4,9,24,48,72$ and $96 \mathrm{~h}$, centrifuged $(6000 \mathrm{rpm}$ for $10 \mathrm{~min})$. The samples were withdrawn with cut tips (proportional amount of solid and liquid) to avoid variations in the liquid to solid ratio, not affecting the subsequent analysis of glucose concentration (analyzed by HPLC).

The cellulose to glucose conversion (CGC) was determined as follow:

$\mathrm{CGC}_{t}=100 \cdot \frac{G_{t}}{G_{\mathrm{pot}}}$

where $\mathrm{CGC}_{t}$ is the cellulose to glucose conversion (\%) at time $t, G_{t}$ is the concentration of glucose obtained at time $t$ and $G_{\text {pot }}$ is the potential glucose calculated as:

$G_{p o t}=\frac{G n}{100} \cdot \frac{180}{162} \frac{\rho}{\mathrm{LSR}+1-\frac{\mathrm{KL}}{100}}$

where $\mathrm{Gn}$ is the glucan content of pretreated solids (g of glucan/ $100 \mathrm{~g}$ of autohydrolyzed solid dry basis), $180 / 162$ is the stoichiometric factor, $\rho$ is the density of the hydrolysis enzymatic medium (average value, $1005 \mathrm{~g} / \mathrm{L}$ ), LSR is the liquid to solid ratio in the considered experiment and $\mathrm{KL}$ is the Klason lignin content of substrate ( $\mathrm{g}$ of Klason lignin/100 $\mathrm{g}$ of oven-dry autohydrolyzed solid).

Table 2

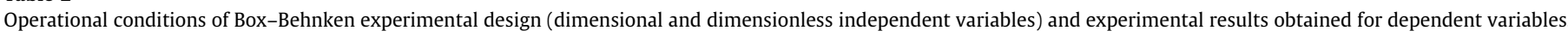

\begin{tabular}{|c|c|c|c|c|c|c|c|c|c|c|}
\hline \multirow[t]{2}{*}{ Run } & \multicolumn{6}{|c|}{ Independent variables } & \multicolumn{4}{|c|}{ Dependent variables } \\
\hline & $\operatorname{LSR}(\mathrm{g} / \mathrm{g}) x_{1}$ & $\operatorname{CSR}(\mathrm{FPU} / \mathrm{g}) x_{2}$ & $\operatorname{HSR}(\mathrm{UI} / \mathrm{g}) x_{3}$ & $x_{1}$ & $x_{2}$ & $x_{3}$ & $\begin{array}{l}G_{96 h}(g / L) \\
y_{1} \\
\end{array}$ & $\begin{array}{l}\mathrm{CGC}_{96 \mathrm{~h}}(\%) \\
y_{2}\end{array}$ & $\begin{array}{l}\mathrm{CGC}_{\max }(\%) \\
y_{3}\end{array}$ & $\begin{array}{l}t_{1 / 2}(\mathrm{~h}) \\
y_{4} \\
\end{array}$ \\
\hline 1 & 4 & 8 & 300 & -1 & -1 & 0 & 63.4 & 37.8 & 43.9 & 14.6 \\
\hline 2 & 25 & 8 & 300 & 1 & -1 & 0 & 18.5 & 64.8 & 74.9 & 10.4 \\
\hline 3 & 4 & 30 & 300 & -1 & 1 & 0 & 102 & 61.0 & 71.4 & 17.6 \\
\hline 4 & 25 & 30 & 300 & 1 & 1 & 0 & 28.1 & 98.8 & 100 & 5.40 \\
\hline 5 & 4 & 19 & 100 & -1 & 0 & -1 & 93.8 & 56.0 & 68.6 & 18.5 \\
\hline 6 & 25 & 19 & 100 & 1 & 0 & -1 & 27.6 & 97.0 & 100 & 7.57 \\
\hline 7 & 4 & 19 & 500 & -1 & 0 & 1 & 108 & 64.7 & 74.6 & 16.2 \\
\hline 8 & 25 & 19 & 500 & 1 & 0 & 1 & 27.1 & 95.1 & 100 & 5.41 \\
\hline 9 & 14.5 & 8 & 100 & 0 & -1 & -1 & 23.2 & 48.8 & 53.0 & 8.95 \\
\hline 10 & 14.5 & 30 & 100 & 0 & 1 & -1 & 45.2 & 94.8 & 100 & 12.6 \\
\hline 11 & 14.5 & 8 & 500 & 0 & -1 & 1 & 40.6 & 85.3 & 100 & 13.0 \\
\hline 12 & 14.5 & 30 & 500 & 0 & 1 & 1 & 47.7 & 100 & 100 & 10.3 \\
\hline 13 & 14.5 & 19 & 300 & 0 & 0 & 0 & 45.9 & 96.2 & 100 & 12.4 \\
\hline 14 & 14.5 & 19 & 300 & 0 & 0 & 0 & 45.8 & 96.2 & 100 & 13.5 \\
\hline 15 & 14.5 & 19 & 300 & 0 & 0 & 0 & 45.9 & 96.2 & 100 & 12.6 \\
\hline
\end{tabular}


Table 3

Regression coefficients and statistical parameters measuring the correlation and significance of the models.

\begin{tabular}{lllll}
\hline Parameters & $G_{96 \mathrm{~h}}(\mathrm{~g} / \mathrm{L})$ & $\mathrm{CGC}_{96 \mathrm{~h}}(\%)$ & $\mathrm{CGC}_{\max }(\%)$ & $\begin{array}{l}t_{1 / 2}(\mathrm{~h}) \\
y 4\end{array}$ \\
\hline$b_{0 j}$ & $45.84^{\mathrm{a}}$ & $96.23^{\mathrm{a}}$ & $100.00^{\mathrm{a}}$ & $11.77^{\mathrm{a}}$ \\
$b_{1 j}$ & $-33.30^{\mathrm{a}}$ & $17.01^{\mathrm{a}}$ & $14.55^{\mathrm{a}}$ & $-4.76^{\mathrm{a}}$ \\
$b_{2 j}$ & $9.68^{\mathrm{a}}$ & $14.75^{\mathrm{a}}$ & $12.45^{\mathrm{a}}$ & -0.12 \\
$b_{3 j}$ & $4.26^{\mathrm{c}}$ & $6.11^{\mathrm{b}}$ & $6.62^{\mathrm{b}}$ & -0.34 \\
$b_{11 j}$ & $16.09^{\mathrm{a}}$ & $-17.35^{\mathrm{a}}$ & $-14.95^{\mathrm{a}}$ & 0.46 \\
$b_{22 j}$ & $-8.93^{\mathrm{b}}$ & $-13.28^{\mathrm{a}}$ & $-12.51^{\mathrm{b}}$ & -0.25 \\
$b_{33}$ & 2.28 & -0.67 & 0.76 & -0.31 \\
$b_{12 j}$ & $-7.27^{\mathrm{b}}$ & 2.70 & -0.60 & $-2.01^{\mathrm{c}}$ \\
$b_{13 j}$ & -3.78 & -2.64 & -1.49 & 0.02 \\
$b_{23 j}$ & -3.70 & $-7.77^{\mathrm{b}}$ & $-11.76^{\mathrm{b}}$ & -1.58 \\
$R^{2}$ & 0.987 & 0.975 & 0.960 & 0.943 \\
$F_{\text {exp }}$ & 41.33 & 21.78 & 13.36 & 9.22 \\
Significance level & $>99$ & $>99$ & $>99$ & $>98$ \\
\hline
\end{tabular}

a Coefficients significance at the $99 \%$ confidence level.

b Coefficients significance at the $95 \%$ confidence level.

c Coefficients significance at the $90 \%$ confidence level.

\subsection{Microorganism, growth conditions and inoculum}

S. cerevisiae PE-2, isolated from Brazilian bioethanol production plant, was used in this work [35]. Stock culture was maintained on YPD $(1 \%(\mathrm{w} / \mathrm{v})$ of yeast extract, $2 \%(\mathrm{w} / \mathrm{v})$ of bacto-peptone and $2 \%$ $(\mathrm{w} / \mathrm{v})$ of glucose) in agar plates at $4{ }^{\circ} \mathrm{C}$. Yeast cells was grown in a medium containing $50 \mathrm{~g} / \mathrm{L}$ of glucose, $20 \mathrm{~g} / \mathrm{L}$ peptone and $10 \mathrm{~g} / \mathrm{L}$ of yeast extract. The inoculum was incubated at $30^{\circ} \mathrm{C}$ in an orbital shaker (200 rpm) for $24 \mathrm{~h}$ (optical density at $600 \mathrm{~nm}$ of 3-4). The biomass was aseptically recovered by centrifugation and resuspended in $0.9 \%(\mathrm{w} / \mathrm{v}) \mathrm{NaCl}$ to a concentration of $200 \mathrm{~g}$ fresh yeast/L. The final concentration of inoculum in the experiments (PSSF and SSF) was $8 \mathrm{~g}$ wet yeast/L or $1.8 \mathrm{~g} / \mathrm{L}$ dry weight.

\subsection{Simultaneous Saccharification and Fermentation (SSF) and Presacchaarification and Simultaneous Saccharification and Fermentation (PSSF)}

SSF and PSSF experiments were carried out in $100 \mathrm{~mL}$ Erlenmeyer flasks fitted with perforated rubber stoppers enclosing glycerol-locks (to allow $\mathrm{CO}_{2}$ releasing and to avoid $\mathrm{O}_{2}$ input) and placed in orbital shaker at $150 \mathrm{rpm}$. The SSF media were prepared under the optimal conditions calculated from experimental design $(\mathrm{LSR}=6.4 \mathrm{~g} / \mathrm{g} ; \mathrm{CSR}=22.4 \mathrm{FPU} / \mathrm{g} ; \mathrm{HSR}=500 \mathrm{UI} / \mathrm{g})$. The SSF experiments (pretreated solid, water and buffer) were autoclaved separately from the nutrients and the hydrolysate. The nutrients were prepared to obtain in the experiments the following concentration: $20 \mathrm{~g} / \mathrm{L}$ of peptone, $10 \mathrm{~g} / \mathrm{L}$ yeast extract. The hydrolysate was sterilized by filtration and added in the amount necessary for each experiment. In PSSF experiment, the flasks were incubated for enzymatic hydrolysis during $24 \mathrm{~h}$ in optimal conditions of enzymes $\left(48.5^{\circ} \mathrm{C}\right)$. After the pre-saccharification stage the temperature was decreased to $35^{\circ} \mathrm{C}$ and the yeast was added. Samples of SSF and PSSF were withdrawn, centrifuged (6000 rpm for $10 \mathrm{~min}$ ) and analyzed for glucose, xylose, arabinose, acetic acid and ethanol concentration. The Ethanol Conversion (EC) was calculated by the following equation:

$\mathrm{EC}=\frac{E_{\max }}{G_{\mathrm{pot}} \cdot 0.511} \cdot 100$

where $E_{\max }$, is the maximal ethanol concentration $(\mathrm{g} / \mathrm{L})$ at time $t$, 0.511 is the stoichiometric factor for glucose conversion into ethanol and $G_{\text {pot }}$ is the potential glucose.

\subsection{Analytical methods}

The raw material and autohydrolyzed EGW were analyzed by TAPPI standards: T-264-cm-07 for extractives and moisture, T211-cm-93 for ash and T-249-em-85 for quantitative acid hydrolysis (QAH). The hydrolysate from pretreatment was analyzed for monosaccharides, oligosaccharides and inhibitor compounds. One aliquot of hydrolysate was subjected to quantitative post-hydrolysis ( $4 \% \mathrm{H}_{2} \mathrm{SO}_{4}, 121{ }^{\circ} \mathrm{C}$ for $20 \mathrm{~min}$ ) for oligosaccharides determination and analyzed by HPLC. The increase in the concentration of sugars and acetic acid provided a measure of oligomers and linked acetyl groups. Second aliquot of hydrolysate was directly analyzed by HPLC for monosaccharides (glucose, xylose and arabinose), hydroxymethylfurfural (HMF), furfural (F) and acetic acid quantification. The samples from enzymatic hydrolysis and fermentation were analyzed for glucose, xylose, arabinose, acetic acid and ethanol concentration by HPLC. The analyses were carried out by HPLC using a Jasco 830-IR intelligent refractive-index detector and a Metacarb $87 \mathrm{H}$ column. Operation was performed at $60^{\circ} \mathrm{C}$ using mobile phase $0.005 \mathrm{M} \mathrm{H}_{2} \mathrm{SO}_{4}$ and flow rate $0.7 \mathrm{~mL} / \mathrm{min}$.

\section{Results and discussion}

\subsection{LCM processing: autohydrolysis pretreatment}

The use of whole-slurry (liquid + solid) coming from EGW autohydrolysis was studied to optimize the enzymatic hydrolysis of cellulose and glucose fermentation yields. Fig. 1 shows the experimental scheme carried out in this work, integrating the evaluated stages: autohydrolysis treatment, enzymatic saccharification and fermentation.

The autohydrolysis conditions were chosen on the basis of previous research [36] in which the overall balance showed $93.8 \%$ of polysaccharide recovery in liquid and solid phase under the selected conditions $\left(T_{\max }=210^{\circ} \mathrm{C}\right)$. As can be observed in Table 1 , in this work the glucan was almost all retained in the solid phase with a $95 \%$ of recovery (expressed as the percentage of glucan present in autohydrolyzed EGW respect to the glucan present in the corresponding amount of oven-dry raw material). The $83.9 \%$ of Klason lignin remained in the pretreated solid (expressed as percentage of lignin in pretreated solid respect to the lignin present in oven-dry raw material). It was observed that part of lignin was solubilized. On the other hand, the percentage of xylan was present in the pretreated solid in low amount (1.4 $\mathrm{g}$ of xylan in pretreated solid/100 g in oven-dry raw material). The composition of hydrolysate was also reported (see Table 1). The hydrolysate was composed mainly by mono- and oligo-saccharides that represent $72.1 \%$ with respect to the total identified compounds in the hydrolysate. The main sugars present in hydrolysate were xylose and xylooligosaccharides ( 7.4 and $7.43 \mathrm{~g} / 100 \mathrm{~g}$ of raw material, respectively). It is important to highlight that the concentration of inhibitor compounds (acetic acid, HMF and furfural) were 2.6, 0.3 and $1.4 \mathrm{~g} / 100 \mathrm{~g}$ in oven-dry raw material, respectively. The presence of degradation compounds causes a substantial inhibition effect on cell growth and ethanol production at concentrations typical for lignocellulose hydrolysate, as have been reported by several authors (reviewed by Almeida et al. [37]). In general, the concentrations of inhibitor compounds obtained in this work are in the range of hydrolysate from hardwoods [25].

\subsection{Enzymatic hydrolysis of whole slurry from autohydrolysis pretreatment: enzymes employed and time course of cellulose to glucose conversion}

The pretreated EGW was mixed with hydrolysate and used as substrate in enzymatic hydrolysis experiments. The enzymes 


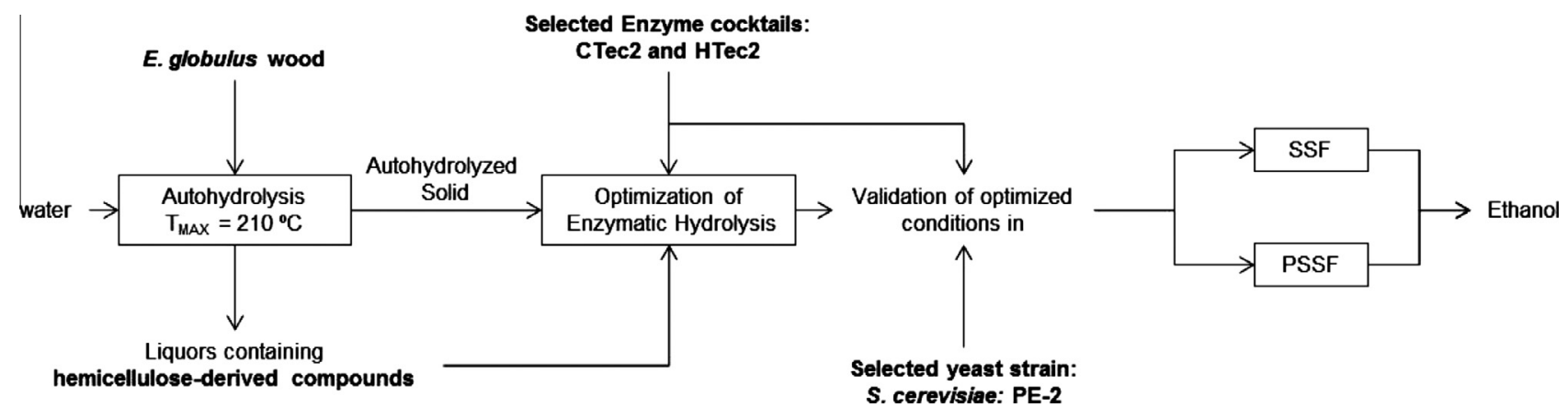

Fig. 1. Integrated approach followed in this study for ethanol production from whole slurry of autohydrolyzed E. globulus wood.

Celluclast $1.5 \mathrm{~L}$ and Cellic CTec2 were assayed for the whole-slurry saccharification under conditions LSR $=6 \mathrm{~g} / \mathrm{g}$ and Enzyme to Solid Ratio $=16 \mathrm{FPU} / \mathrm{g}$. The activity of Celluclast $1.5 \mathrm{~L}$ was $44 \pm 3.55 \mathrm{FPU} / \mathrm{mL}$ and was measured as described in Section 2.3. Overall, the results obtained using Cellic CTec2 were more satisfactory than the results achieved by Celluclast (supplemented with Novozyme 188). The glucose concentration using Cellic CTec2 was $80.6 \mathrm{~g} / \mathrm{L}$ (corresponding to $76.4 \%$ of conversion) and the glucose achieved by Celluclast $1.5 \mathrm{~L}$ was $50.2 \mathrm{~g} / \mathrm{L}$ (conversion of $51.6 \%$ ) using the whole-slurry. This behavior was also observed by Cannella et al. [38] that obtained a cellulose conversion $25 \%$ lower from hydrothermally pretreated wheat straw at $30 \%$ of solids using Celluclast/Novozyme 188 compared to Cellic CTec2. Additionally, the results obtained in this work are in agreement with previous study [39] in which the inhibitory effect of hemicellulosic liquid phase (HLP) on enzymatic hydrolysis was studied using Celluclast $1.5 \mathrm{~L}$ and Novozyme 188 . This study showed that the use of $100 \%$ HLP decreased the enzymatic conversion of cellulose from $88 \%$ to $55 \%$ at $\mathrm{LSR}=6 \mathrm{~g} / \mathrm{g}$ and enzyme loading of $25 \mathrm{FPU} / \mathrm{g}$. Moreover, the addition of xylanases had a positive effect with an increase of $35 \%$ of glucose concentration (operating $4 \mathrm{UI} / \mathrm{FPU}$ at $\mathrm{LSR}=6 \mathrm{~g} / \mathrm{g}$ and $\mathrm{ESR}=16 \mathrm{FPU} / \mathrm{g}$ ). Based on the results achieved in these preliminary experiments, the selected enzymes employed for enzymatic optimization study were the novel enzymes Cellic Ctec2 and Cellic HTec2. The hemicellulase was used to avoid the inhibition of cellulase produced by the presence of xylooligosaccharides. This fact has been documented in several studies $[20,40]$. The inhibition could be related with the binding of xylooligosaccharides to cellobiohydrolases (CBHI) from $T$. reesei and with a competitive mechanism for xylooligosaccharides of CBHI [41].

The enzymatic hydrolysis experiments were carried out under the operational conditions listed in Table 2. Different solid and enzyme loadings were studied for the optimization of enzymatic operational conditions with the target to obtain high concentration of glucose and increase the cellulose conversion yield. The glucose concentration at $96 \mathrm{~h}$ for each experiment $\left(G_{96 \mathrm{~h}}\right.$ or $\left.y_{1}\right)$ is indicated in Table 2. As can be observed, the glucose concentration varied in the range of 18.5-108.4 g/L (experiments 2 and 7, respectively) corresponding to the highest and the lowest LSR (25 and $4 \mathrm{~g} / \mathrm{g}$, respectively). Glucose concentrations $>45 \mathrm{~g} / \mathrm{L}$ were obtained with $\mathrm{LSR}=14.5 \mathrm{~g} / \mathrm{g}$ for enzyme loadings of 19 and $30 \mathrm{FPU} / \mathrm{g}$. Nevertheless, minor concentration of glucose $(23.4 \mathrm{~g} / \mathrm{L})$ was achieved with low amount of enzyme ( $8 \mathrm{FPU} / \mathrm{g}$ ). Interestingly, the addition of $500 \mathrm{UI} / \mathrm{FPU}$ of hemicellulase allowed a higher glucose concentration $\left(40 \mathrm{~g} / \mathrm{L}\right.$ ) with $8 \mathrm{FPU} / \mathrm{g}$. The $\mathrm{CGC}_{96 \mathrm{~h}}$ at $96 \mathrm{~h}$ (or $\left.y_{2}\right)$ was reported in Table 2 and varied in the range $37.8-100 \%$, obtained in experiments 1 and 12 , respectively. The $\mathrm{CGC}_{96 \mathrm{~h}}=37.8 \%$ was achieved for the lowest studied conditions of LSR and ESR $(4 \mathrm{~g} / \mathrm{g}$ and $8 \mathrm{FPU} / \mathrm{g}$ ) and intermediate amounts of HSR (300 UI/FPU). On the other hand, the highest conversion of cellulose was reached at intermediate LSR (14.4 g/g) and higher enzyme loadings (30 FPU/ g). Remarkably, for $8 \mathrm{FPU} / \mathrm{g}$ of cellulase loading $\mathrm{CGC}_{96 \mathrm{~h}}$ was improved when the hemicellulases addition was $500 \mathrm{UI} / \mathrm{g}$ comparing with $100 \mathrm{UI} / \mathrm{g}$ (achieving $85.3 \%$ and $48.8 \%$ of conversion respectively, run 11 and 9). Nevertheless, this improvement was not significant when the cellulase addition was higher (30 FPU/g) obtaining $94 \%$ and $100 \%$ of conversion for 100 and $500 \mathrm{UI} / \mathrm{g}$ (run 10 and 12). The xylose was also measured and was present in concentrations of $13.6-21.4 \mathrm{~g} / \mathrm{L}$ at the end of saccharification (data no shown). The increase of xylose is the result of saccharification of xylooligosaccharides from hydrolysate and the hydrolysis of xylan left in the autohydrolyzed EGW. The conversion of xylan and xylooligosaccharides into xylose was in the range of 81.5-100\%.

In general, the results achieved in this study can be compared favorably with the literature data using the whole-slurry strategy. Arvaniti et al. [42] reported a glucose yield of $45 \%$ using rape straw treated by wet oxidation $\left(195^{\circ} \mathrm{C}, 15 \mathrm{~min}\right.$ and $\left.15 \mathrm{bar}\right)$ with $17 \%$ solid loading and $15 \mathrm{FPU} / \mathrm{g}$. On the other hand, Hodge et al. [43] obtained a concentration of glucose $<80 \mathrm{~g} / \mathrm{L}$ employing pretreated corn stover by dilute sulfuric acid, (corresponding to $70 \%$ of conversion) when the enzyme loading was $17 \mathrm{mg} / \mathrm{g}$. Further, in this same study, when the addition of enzyme was $52 \mathrm{mg} / \mathrm{g}, 100 \mathrm{~g} / \mathrm{L}$ of glucose were produced with a $90 \%$ of conversion. Moreover, Alvira et al. [24] used wheat straw processed by steam explosion $\left(210{ }^{\circ} \mathrm{C}\right.$ during $\left.2.5 \mathrm{~min}\right)$ as substrate in enzymatic hydrolysis at $10 \%$ of solids adding cellulase, xylanase and arabinofuranosidase and the authors obtained a glucose concentration of $16 \mathrm{~g} / \mathrm{L}$ with a conversion $<50 \%$.

Fig. 2 shows the time course of cellulose to glucose conversion (CGC) of enzymatic hydrolysis for each experiment. The experiments carried out at LSR $25 \mathrm{~g} / \mathrm{g}$ achieved a maximal conversion yield of $85 \%$ at $24 \mathrm{~h}$ of saccharification. As can be observed in Fig. 2, the kinetic showed a typical pattern. In this sense, the experimental data were fitted to the following equation [44]:

$\mathrm{CGC}_{t}=\mathrm{CGC}_{\max } \cdot \frac{t}{t+t_{1 / 2}}$

where $\mathrm{CGC}_{t}$ is the cellulose to glucose conversion (\%) at time $t$, $\mathrm{CGC}_{\max }$ is the cellulose to glucose conversion predicted for an infinite reaction time, $t$ is the enzymatic saccharification time $(h), t_{1 / 2}$ (h) is the time needed to reach $C G C=C_{\text {max }} / 2$.

Table 2 shows the results calculated by Eq. (9) for the variable $\mathrm{CGC}_{\max }$ and $t_{1 / 2}$ (or $y_{3}$ and $y_{4}$ ). For most of experiments, $\mathrm{CGC}_{\max }$ was $>70 \%$, except in the experiments 1 and 9 in which the $\mathrm{CGC}_{\max }$ was $<55 \%$. The value of $t_{1 / 2}$ for enzymatic saccharification was in the range 5.4-18.5 h corresponding to extremes values of LSR 25 and $4 \mathrm{~g} / \mathrm{g}$, respectively. High solid loading may hinder the enzymatic saccharification as a result of insufficient mass transfer (as water is not available) [21]. 

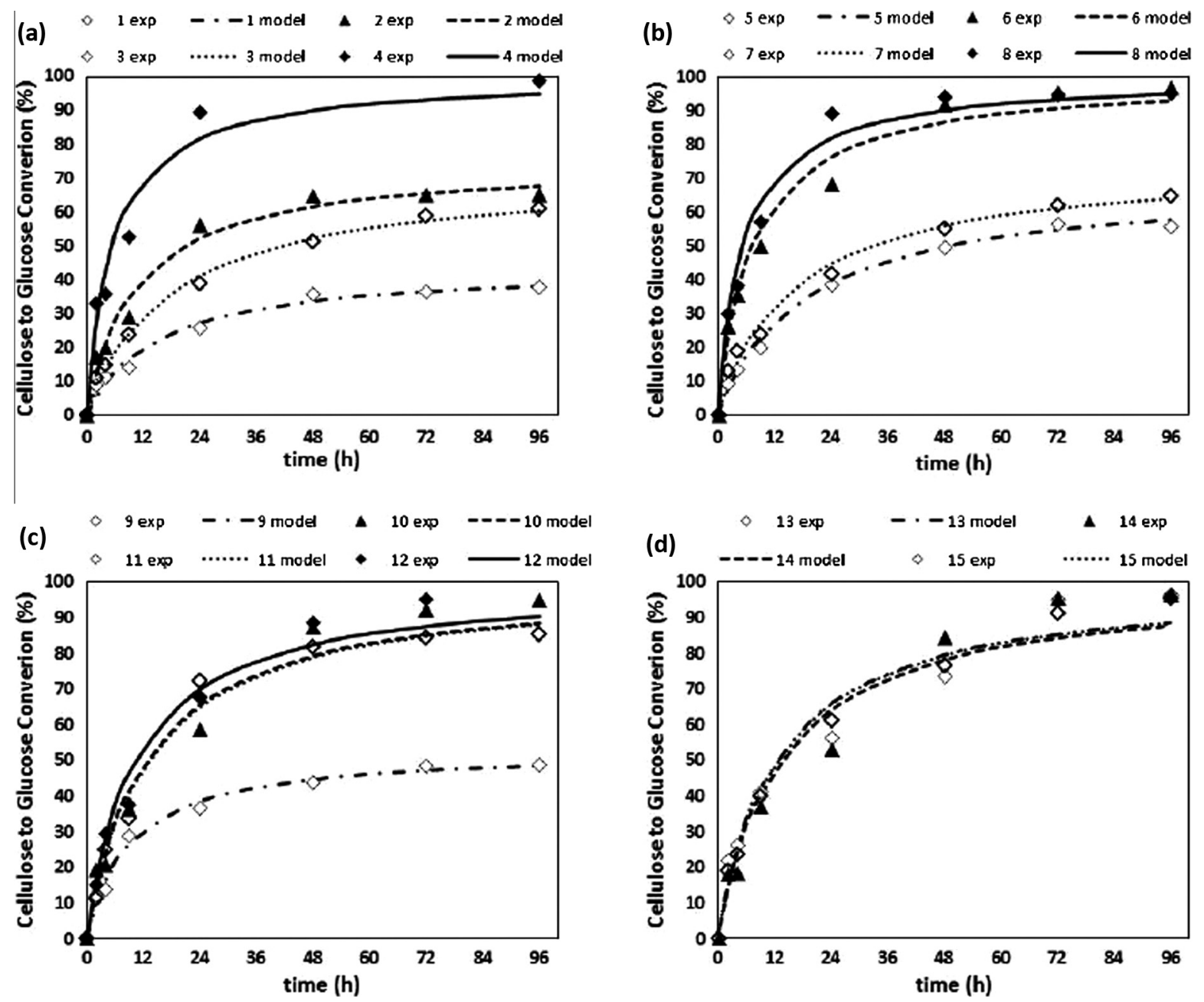

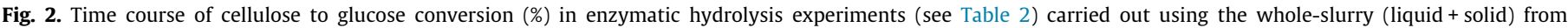
autohydrolyzed E. globulus wood: experimental points (symbols) and model prediction (lines): (a) run 1 to 4 ; (b) run 5 to 8 ; (c) run 9 to 12 ; (d) run 13 to 15 .

\subsection{Response surface methodology assessment}

For a better interpretation and evaluation of results, the independent variables (LSR, CSR and HSR) and dependent variables $\left(G_{96 \mathrm{~h}}, \mathrm{CGC}_{96 \mathrm{~h}}, \mathrm{CGC}_{\max }\right.$ and $\left.t_{1 / 2}\right)$ listed in Table 2 were correlated using the empirical polynomial described previously (see, Eq. (5). Table 3 shows the good fitting of results (0.94-0.99). The high $R^{2}$ with an average value of 0.97 displays a good correlation of data. In addition, the elevated values of $F$ also confirmed a good adjustment of data.

Fig. 3a and b shows the predicted dependence of $G_{96 h}$ and $\mathrm{CGC}_{96 \mathrm{~h}}$ values as function of LSR and CSR. The variable Hemicellulase to Substrate Ratio (HSR) was the least influential variable. Therefore, the HSR was fixed at 500 UI/FPU in Fig. 3a and b for its representation. The most statistically significant variable on glucose concentration was the LSR. As can be observed in Fig. 3a, the glucose concentration increased with a decrease of LSR. On the other hand, it is important to highlight that the increase of cellulase loading above $19 \mathrm{FPU} / \mathrm{g}$ was not necessary for a significant rise of glucose concentration. The maximal predicted concentration of glucose $(101 \mathrm{~g} / \mathrm{L})$ was obtained under the follow conditions: $\mathrm{LSR}=4 \mathrm{~g} / \mathrm{g}, \mathrm{CSR}=30 \mathrm{FPU} / \mathrm{g}$ and $\mathrm{HSR}=300 \mathrm{UI} / \mathrm{FPU}$. Fig. $3 \mathrm{~b}$ shows the influence of LSR and CSR on CGC $_{96 h}$. Conversions above 90\% were obtained for values of CSR in the range 19-23.4 FPU/g and conditions of LSR $>9 \mathrm{~g} / \mathrm{g}$. The surface of Fig. 3b shows an optimal condition $\left(100 \%\right.$ of $\left.\mathrm{CGC}_{96 \mathrm{~h}}\right)$ corresponding to $\mathrm{LSR}=19 \mathrm{~g} / \mathrm{g}$,
$\mathrm{CSR}=21.9 \mathrm{FPU} / \mathrm{g}$ and $\mathrm{HSR}=100 \mathrm{UI} / \mathrm{FPU}$. As can be observed, the maximal enzyme loading was not necessary to achieve the maximal conversion of cellulose to glucose.

Fig. $3 c$ and $d$ shows the dependence of predicted values of $\mathrm{CGC}_{\max }$ and $t_{1 / 2}$ with independent variables. In a wide range of the studied variables the $\mathrm{CGC}_{\max }$ achieved values of $100 \%$ (LSR $>12.5 \mathrm{~g} / \mathrm{g}$ and CSR $>20 \mathrm{FPU} / \mathrm{g}$, see Fig. $3 \mathrm{c}$ ). For $\mathrm{LSR}=6.1 \mathrm{~g} / \mathrm{g}$ (equivalent to $16.4 \%$ of percentage solid) the $\mathrm{CGC}_{\max }$ was $\geqslant 80 \%$ when the cellulase addition was above of $24.5 \mathrm{FPU} / \mathrm{g}$. Fig. $3 \mathrm{~d}$ represents the influence of LSR and HSR on the $t_{1 / 2}$. Values of $t_{1 / 2}<5 \mathrm{~h}$ were obtained for HSR $>380 \mathrm{UI} / \mathrm{FPU}$ and LSR $>23 \mathrm{~g} / \mathrm{g}$. The most influent variable on $t_{1 / 2}$ was the LSR (see Table 3 ) and the other variables did not have a significant influence.

\subsubsection{Optimization and model validation}

In second generation bioethanol, the obtainment of high glucose concentration during enzymatic hydrolysis step is important to maximize the final ethanol titers and consequently decrease the cost involved in the distillation stage [21]. In this context, these results show that the highest LSR $(25 \mathrm{~g} / \mathrm{g})$ achieved elevated conversion (98.8\%), however the glucose concentration under these conditions was very low $(28.1 \mathrm{~g} / \mathrm{L})$ for industrial interests. In order to optimize the whole-slurry saccharification process, an optimal condition was calculated on basis to obtain the maximal concentration and conversion of glucose. Thus, the variables $G_{96 \mathrm{~h}}$ and $\mathrm{CGC}_{96 \mathrm{~h}}$ were used as response variable for the multiple response 
(a)

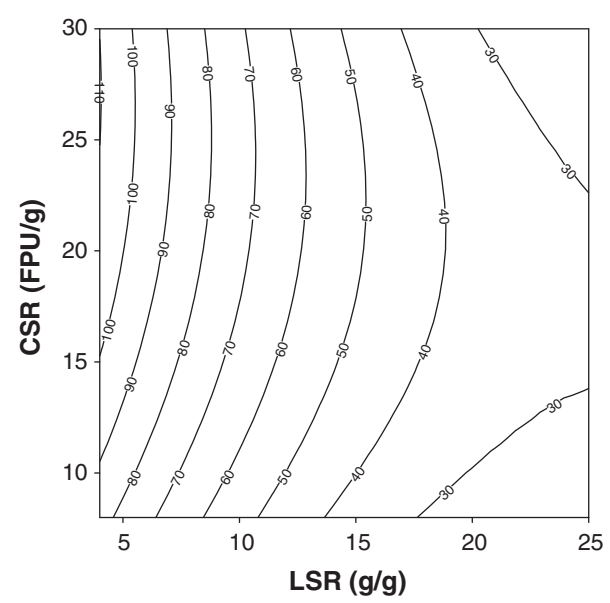

(c)

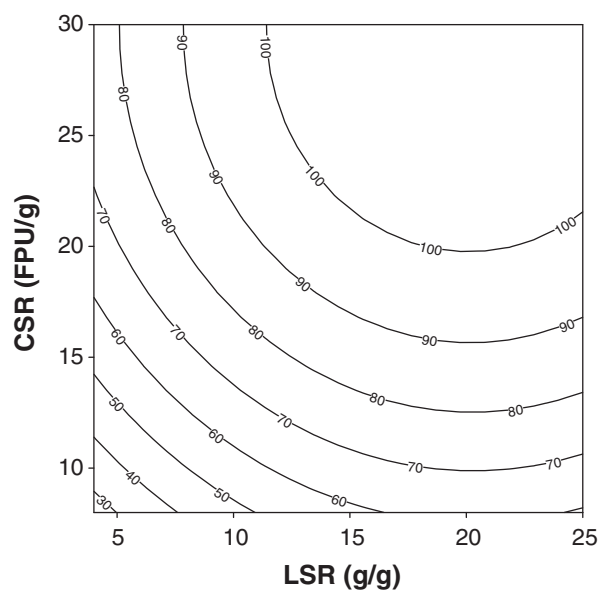

(b)

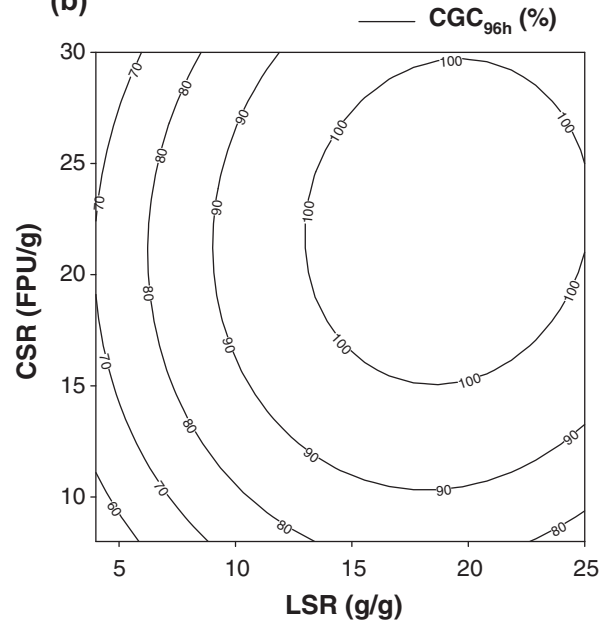

(d) $-\mathbf{t}_{1 / 2}(\mathrm{~h})$

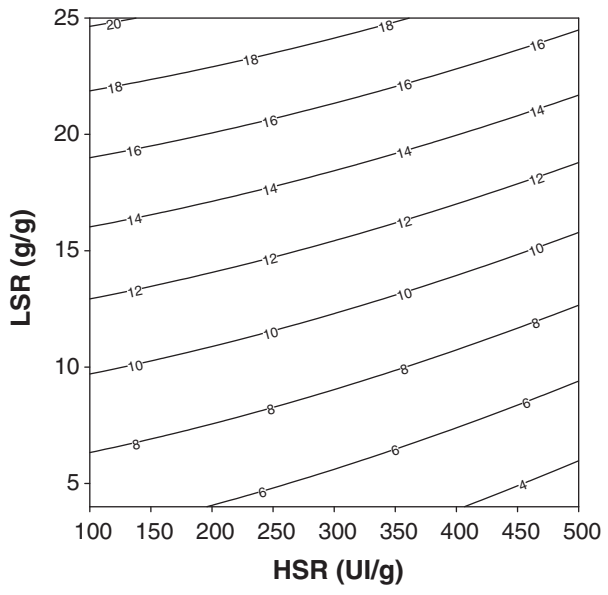

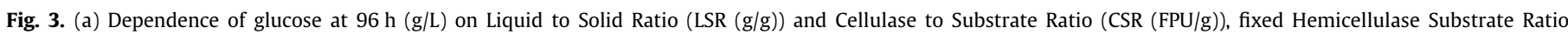

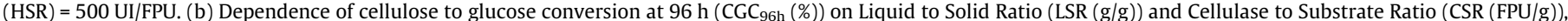

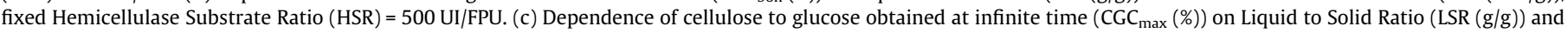

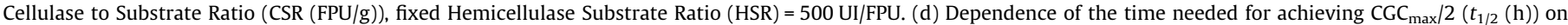
Liquid to Solid Ratio (LSR (g/g)) and Hemicellulase Substrate Ratio (HSR (UI/FPU)), fixed cellulase substrate ratio (CSR) = 30 FPU/g.

optimization of model. The maximal predicted conversion and concentration were obtained employing the following operational conditions: $\mathrm{LSR}=6.4 \mathrm{~g} / \mathrm{g}, \mathrm{CSR}=22.5 \mathrm{FPU} / \mathrm{g}$ and $\mathrm{HSR}=500 \mathrm{UI} / \mathrm{FPU}$. The predicted glucose concentration and cellulose conversion were $93.5 \mathrm{~g} / \mathrm{L}$ and $86.3 \%$, respectively. For the validation of model, an additional assay was carried out under the mentioned conditions. The results of validation assay were $85.5 \mathrm{~g} / \mathrm{L}$ of glucose and $81.3 \%$ of cellulose to glucose conversion, the relative error was $8.5 \%$ and $5.8 \%$, respectively. These data verify the sustainability of the model for reproducing and predicting the experimental results.

\subsection{Simultaneous saccharification and fermentation of optimal condition}

On the basis of reported data, saccharification and fermentation experiments of whole-slurry were carried out under optimized conditions $(\mathrm{LSR}=6.4 \mathrm{~g} / \mathrm{g}, \mathrm{CSR}=22.4 \mathrm{FPU} / \mathrm{g}$ and $\mathrm{HSR}=500 \mathrm{UI} / \mathrm{FPU}$ ). The use of hydrolysate has an inhibitory effect on the saccharification and fermentation and this inhibition will depend on the compounds concentration $[45,46]$. Therefore, the selection of suitable microorganism for the fermentation in presence of inhibitor compounds is determinant for a good fermentation performance $[27,47]$. The strain used in this work was selected in previous study in which the S. cerevisiae PE-2 showed the best capacity of fermentation in presence of hydrolysate from autohydrolyzed E. globulus in comparison with several industrial and laboratory background strains [28]. Considering the xylose present in the hydrolysate, one of the main challenges in the bioethanol from LCM is the engineering of robust microorganisms able to rapidly ferment all sugars present in the hydrolysate [27]. In this context, the selected strain may be used as host for engineer desired physiological characteristics as xylose fermentation, following the physiological engineering concept [48]. The use of whole-slurry strategy poses some challenges including the hydrolysate inhibitory effect on yeast growth and fermentation [26] and moreover, the different optimal temperature for saccharification and fermentation processes [29]. For these reasons, different percentages of hydrolysate (65\%, 70\%, 75\% and $100 \%$ ) were assayed at 30,35 and $37^{\circ} \mathrm{C}$ in separate hydrolysis and fermentation (data not shown). These results showed a strong inhibition of fermentation with the increase of the hydrolysate percentage and temperature. On basis of these preliminary results, the experimental conditions chosen for sequent 

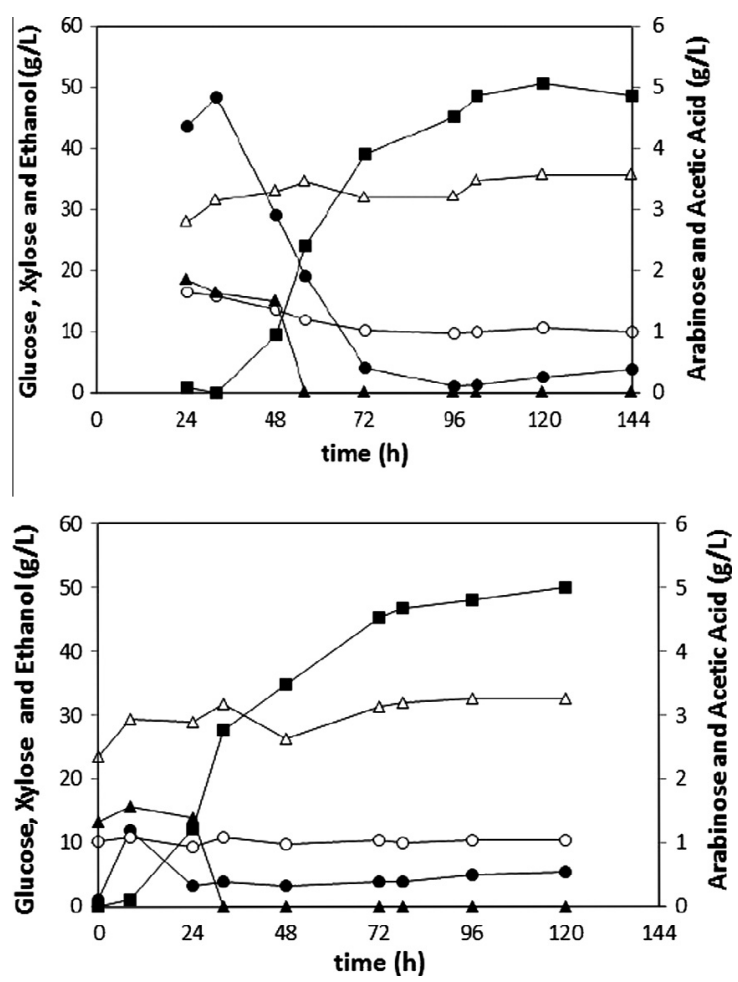

Fig. 4. Time course of glucose $(\bullet)$, xylose $(O)$, arabinose $(\Delta)$, acetic acid $(\triangle)$ and ethanol ( $\square$ ) concentration in optimized conditions (LSR $=6.4 \mathrm{~g} / \mathrm{g} ; \mathrm{ESR}=22.5 \mathrm{FPU} / \mathrm{g}$ and $\mathrm{HSR}=500 \mathrm{UI} / \mathrm{FPU}$ ) (a) by Presaccharification of $24 \mathrm{~h}$ and Simultaneous Saccharification and Fermentation (PSSF). (b) By Simultaneous Saccharification and Fermentation (SSF).

Table 4

Operational conditions used and results obtained in PSSF and SSF experiments using whole-slurry (70\% liquid + solid).

\begin{tabular}{|c|c|c|c|c|c|c|}
\hline \multirow[t]{2}{*}{ Experiment } & \multicolumn{3}{|c|}{ Operational conditions } & \multicolumn{3}{|l|}{ Results } \\
\hline & LSR (g/g) & ESR (FPU/g) & HSR (UI/g) & Qp72 (g/L h) & $\operatorname{Emax}(\mathrm{g} / \mathrm{L})$ & $\mathrm{EC}(\%)$ \\
\hline SSF & 6.4 & 22.5 & 500 & 0.63 & 50.2 & 94.7 \\
\hline PSSF & 6.4 & 22.5 & 500 & 0.55 & 48.8 & 92.1 \\
\hline
\end{tabular}

$\mathrm{Q}_{\mathrm{p} 72}$ : productivity obtained at $72 \mathrm{~h}(\mathrm{~g} / \mathrm{L} \mathrm{h})$.

$E_{\max }$ : maximal concentration of ethanol $(\mathrm{g} / \mathrm{L})$

EC: Ethanol Conversion (\%).

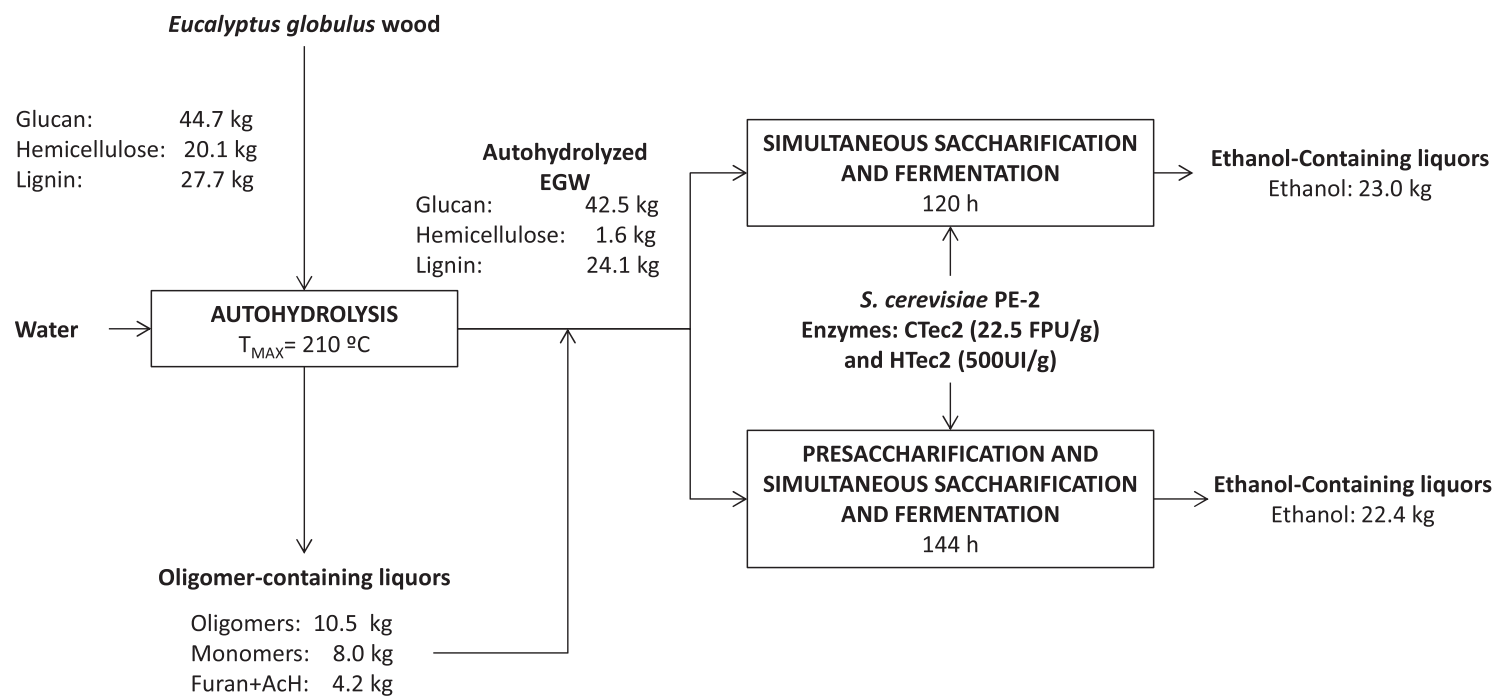

Fig. 5. Mass balances for SSF and PSSF experiments. 
et al. [50] reported an $81.5 \%$ of ethanol yield and $21.4 \mathrm{~g} / \mathrm{L}$ of ethanol using whole slurry from steam-pretreated corn stover with additional xylanases supplementation by SSF. On the other hand, Varga et al. [51] achieved $52 \mathrm{~g} / \mathrm{L}$ of ethanol (6\% v/v) corresponding to $78 \%$ ethanol yield by SSF from wet oxidized corn stover dry matter $(17 \%$ of solid and enzyme loading of $43.5 \mathrm{FPU} / \mathrm{g}$ cellulose). In other study where SSF was carried out with whole steam-pretreated spruce slurry at $13.7 \%$ of solid, very low ethanol yield was obtained, however the yield increased from $3.9 \%$ to $62.1 \%$ when a prehydrolysis $\left(48^{\circ} \mathrm{C}\right.$ for $\left.24 \mathrm{~h}\right)$ was realized [52].

The results obtained in this work confirmed the good performance of fermentation with high productivity $\left(Q_{\mathrm{p} 72}>0.6 \mathrm{~g} / \mathrm{L} \mathrm{h}\right)$ and elevated ethanol concentration (higher than $6 \%, v / v$ ), even comparing to literature. The use of an industrial robust strain, naturally more resistant to overall stress conditions (including stress induced by inhibitors), could provide an essential key for the attainment of an efficient fermentation step that allow the ethanol process from lignocellulosic materials. Considering the overall balance of the process, the potential ethanol from cellulose presents in EGW is $26.98 \mathrm{~kg} / 100 \mathrm{~kg}$ wood (see Fig. 5), therefore the ethanol yield of whole-slurry SSF and PSSF processes obtained in this work is $85.3 \%$ and $82.9 \%$, respectively.

\section{Conclusion}

This work provides results for the development of ethanol production process using the whole slurry from autohydrolyzed $E$. globulus wood at high solid loadings that could help to establish a cost-effective process. New advanced cellulolytic enzymes preparation ( $\mathrm{CTec} 2$ and $\mathrm{HTec} 2$ ) showed better results for saccharification of whole-slurry from autohydrolyzed EGW than Celluclast $1.5 \mathrm{~L} /$ Novozyme 188 . The glucose concentration was optimized by experimental design and $85.5 \mathrm{~g} / \mathrm{L}$ was obtained corresponding to a conversion of $81.5 \%$ operating under the following conditions: $\mathrm{LSR}=6.4 \mathrm{~g} / \mathrm{g}, \mathrm{CSR}=22.5 \mathrm{FPU} / \mathrm{g}$ and $\mathrm{HSR}=500 \mathrm{IU}$. The saccharification and fermentation of pretreated solid was carried out with $70 \%$ of hydrolysate using an industrial yeast strain. The SSF strategy was more advantageous than PSSF. The highest ethanol concentration $(50 \mathrm{~g} / \mathrm{L}$ or $6.3 \%(\mathrm{v} / \mathrm{v}))$ was obtained using high solid loadings and no-detoxified hydrolysate with elevated conversion (95\%) contributing to obtain a robust process in the field of second generation bioethanol.

\section{Acknowledgements}

The authors A. Romaní and F.B. Pereira thank to the "Fundação para a Ciência e a Tecbologia" (FCT, Portugal) for their fellowships (grant number, SFRH/BPD/77995/2011 and SFRH/BD/64776/2009, respectively) and Gil Garrote (University of Vigo, Spain) for assistance in the pre-treatment of EGW. Research described in this article was financially supported by FEDER and FCT: Strategic Project PEst-OE/EQB/LA0023/2013, Project "BioInd - Biotechnology and Bioengineering for improved Industrial and Agro-Food processes, REF. NORTE-07-0124-FEDER-000028" Co-funded by the Programa Operacional Regional do Norte (ON.2 - O Novo Norte) QREN, FEDER.

\section{References}

[1] Ayeni AO, Hymore FK, Mudliar SN, Deshmukh SC, Satpute DB, Omoleye JA, et al. Hydrogen peroxide and lime based oxidative pretreatment of wood waste to enhance enzymatic hydrolysis for a biorefinery: process parameters optimization using response surface methodology. Fuel 2013;106:187-94.

[2] Ruiz HA, Rodríguez-Jasso RM, Fernandes BD, Vicente AA, Teixeira JA. Hydrothermal processing, as an alternative for upgrading agriculture residues and marine biomass according to the biorefinery concept: a review. Renew Sust Energy Rev 2013;21:35-51.

[3] Gullón P, Romaní A, Vila C, Garrote G, Parajó JC. Potential of hydrothermal treatments in lignocellulose biorefineries. Biofuels Bioprod Bioref 2012:6:219-32.

[4] Moniz P, Pereira H, Quilhó T, Carvalheiro F. Characterisation and hydrothermal processing of corn straw towards the selective fraction of hemicelluloses. Ind Crops Prod 2013;50:145-53.

[5] Yáñez R, Romaní A, Garrote G, Alonso JL, Parajó JC. Processing of Acacia dealbata in aqueous media: first step of a wood biorefinery. Ind Eng Chem Res 2009;48(14):6618-26.

[6] Cardona E, Rios J, Peña J, Rios L. Effects of the pretreatment method on enzymatic hydrolysis and ethanol fermentability of the cellulosic fraction from elephant grass. Fuel 2014;118:41-7.

[7] Kang KE, Han M, Moon S-K, Kang H-W, Kim Y, Cha Y-L, et al. Optimization of alkali-extrusion pretreatment with twin-screw for bioethanol production from Miscanthus. Fuel 2013;109:520-6.

[8] Talebnia F, Karakashev D, Angelidaki I. Production of bioethanol from wheat straw: an overview on pretreatment, hydrolysis and fermentation. Bioresour Technol 2010;101(13):4744-53.

[9] Garrote G, Domínguez H, Parajó JC. Hydrothermal processing of lignocellulosic materials. Holz Roh Werkst 1999;57:191-202.

[10] Balat M. Production of bioethanol from lignocellulosic materials via the biochemical pathway: a review. Energy Convers Manage 2011;52(2):858-75.

[11] Limayem A, Ricke SC. Lignocellulosic biomass for bioethanol production: current perpectives, potential issues and future prospects. Prog Energy Combust Sci 2012;38(4):449-67.

[12] Tomás-Pejó E, Oliva JM, González A, Ballesteros I, Ballesteros M. Bioethano production from wheat straw by the thermotolerant yeast Kluyveromyces marxianus CECT 10875 in a simultaneous saccharification and fermentation fed-batch process. Fuel 2009;88(11):2142-7.

[13] Romaní A, Garrote G, Parajó JC. Bioethanol production from autohydrolyzed Eucalyptus globulus by simultaneous saccharification and fermentation operating at high solids loading. Fuel 2012;94:305-12.

[14] Tengborg C, Galbe M, Zacchi G. Reduced inhibition of enzymatic hydrolysis of steam-pretreated softwood. Enzyme Microb Technol 2001:28(9-10):835-44.

[15] Kim Y, Ximenes E, Mosier NS, Ladisch MR. Soluble inhibitors/deactivators of cellulase enzymes from lignocellulosic biomass. Enzyme Microb Technol 2011;48(4-5):408-15.

[16] Alvira P, Moreno AD, Ibarra D, Sáez F, Ballesteros M. Improving the fermentation performance of Saccharomyces cerevisiae by laccase during ethanol production from steam-exploded wheat straw at high-substrate loadings. Biotechnol Prog 2012;29(1):74-82.

[17] Sivers MV, Zacchi G, Olsson L, Hahn-Hägerdal B. Cost analysis of ethanol production from willow using recombinant Echerichia coli. Biotechnol Prog 1994;10:555-60.

[18] Parawira W, Tekere M. Biotechnological strategies to overcome inhibitors in lignocellulose hydrolysates for ethanol production: review. Crit Rev Biotechnol 2011;31(1):20-31.

[19] Duarte GC, Moreira LRS, Jaramillo PMD, Filho EXF. Biomass-derived inhibitors of holocellulases. Bioenergy Res 2012;5(3):768-77.

[20] Ximenes E, Kim Y, Mosier N, Dien B, Ladisch M. Inhibition of cellulases by phenols. Enzyme Microb Technol 2010;46(3-4):170-6.

[21] Modenbach AA, Nokes SE. Enzymatic hydrolysis of biomass at high-solids loadings - a review. Biomass Bioenergy 2013;56:526-44.

[22] Gusakov AV. Alternatives to Trichoderma reesei in biofuel production. Trends Biotechnol 2011;29(9):419-25.

[23] Geddes CC, Nieves IU, Ingram LO. Advances in ethanol production. Curr Opin Biotechnol 2011;22(3):312-9.

[24] Alvira P, Negro MJ, Ballesteros M. Effect of endoxylanase and $\alpha-L-$ arabinofuranosidase supplementation on the enzymatic hydrolysis of steam exploded wheat straw. Bioresour Technol 2011;102(6):4552-8.

[25] Klinke HB, Thomsen AB, Ahring BK. Inhibition of ethanol-producing yeast and bacteria by degradation products produced during pre-treatment of biomass. Appl Microbiol Biotechnol 2004;66(1):10-26.

[26] Palmqvist E, Hanh-Hägerdal B. Fermentation of lignocellulosic hydrolysastes. II: inhibitors and mechanisms of inhibition. Bioresour Technol 2000;74(1):25-33.

[27] Demeke MM, Dumortier F, Li Y, Broeckx T, Foulquié-Moreno MR, Thevelein JM. Combining inhibitor tolerance and D-xylose fermentation in industrial Saccharomyces cerevisiae for efficient lignocellulose-based bioethanol production. Biotechnol Biofuels 2013;6:20.

[28] Pereira FB, Romaní A, Ruiz HA, Teixeira JA, Domingues L. Industrial robust yeast isolates with great potential for fermentation of lignocellulosic biomass. Bioresour Technol 2014;161:192-9.

[29] Mesa L, González E, Romero I, Ruiz E, Cara C, Castro C. Comparison of process configurations for ethanol production from two-step pretreated sugarcane bagasse. Chem Eng J 2011;175:185-91.

[30] Romaní A, Garrote G, Alonso JL, Parajó JC. Experimental assessment on the enzymatic hydrolysis of hydrothermally pretreated Eucalyptus globulus wood. Ind Eng Chem Res 2010;49(10):4653-63.

[31] Ghose TS. Measurement of cellulase activities. Pure Appl Chem 1986;59:257-68.

[32] Paquot M, Thonart P. Hydrolyse enzymatique de la cellulose régénérée. Holzforschung 1982;36:177-81. 
[33] Bailey MJ, Biely P, Poutanen K. Interlaboratory testing of methods for assay of xylanase activity. J Biotechnol 1992;23:257-72.

[34] Aslan N, Cebeci Y. Application of Box-Behnken design and response surface methodology for modeling of some Turkish coals. Fuel 2007;86:90-7.

[35] Pereira FB, Guimarães PMR, Teixeira JA Domingues L. Selection of Saccharomyces cerevisiae strains for efficient very high gravity bio-ethanol fermentation processes. Biotechnol Lett 2010;32(11):1655-61.

[36] Romaní A, Garrote G, Alonso JL, Parajó JC. Bioethanol production from hydrothermally pretreated Eucalyptus globulus wood. Bioresour Technol 2010;101:8706-12.

[37] Almeida JRM, Bertilsson M, Gorwa-Grauslund MF, Gorsich S, Lidén G. Metabolic effects of furaldehydes and impacts on biotechnological processes. Appl Microbiol Biotechnol 2009;82:625-38.

[38] Cannella D, Hsieh CW, Felby C, Jorgensen H. Production and effect of aldonic acids during enzymatic hydrolysis of lignocellulose at high dry matter content. Biotechnol Biofuels 2012;5:26.

[39] Romaní A, Ruiz HA, Pereira FB, Domingues L, Teixeira JA. Effect of hemicellulose liquid phase on the enzymatic hydrolysis of autohydrolyzed Eucalyptus globulus wood. Biomass Convers Biorefinery 2013:4(2):77-86.

[40] Kumar R, Wyman CE. Effect of enzyme supplementation at moderate cellulase loading on initial glucose and xylose release from corn stover solids pretreatment by leading technologies. Biotechnol Bioeng 2009;102(2):457.

[41] Baumann MJ, Borch K, Westh P. Xylan oligosaccharides and cellobiohydrolase I (TrCel7A) interaction and effect on activity. Biotechnol Biofuels 2011;4:45.

[42] Arvaniti E, Bjerre AB, Schmidt JE. Wet oxidation pretreatment of rape straw for ethanol production. Biomass Bioenergy 2012;39:94-105.

[43] Hodge DB, Karim MN, Schell DJ, McMillan JD. Soluble and insoluble solids contributions to high-solids enzymatic hydrolysis of lignocellulose. Bioresour Technol 2008;99(18):8940-8.
[44] Holtzapple MT, Caram HS, Humphrey AE. A comparison of two empirical models for enzymatic hydrolysis of pretreated poplar wood. Biotechnol Bioeng 1984;26(8):936-41.

[45] Huang H, Guo X, Li D, Liu M, Wu J, Ren H. Identification of crucial yeast inhibitors in bio-ethanol and improvement of fermentation at high $\mathrm{pH}$ and high total solids. Bioresour Technol 2011;102(16):7486-93.

[46] Taylor MP, Mulako I, Tuffin M, Cowan DA. Understanding physiological responses to pre-treatment inhibitors in the ethanologenic fermentations. Biotechnol J 2012;7:1169-81.

[47] Hawkins GM, Doran-Peterson JD. A strain of Saccharomyces cerevisiae evolved for fermentation of lignocellulosic biomass displays improved growth and fermentative ability in high solids concentrations and in the presence of inhibitory compounds. Biotechnol Biofuels 2011;4:49.

[48] Zhang Y, Zhu Y, Zhu Y, Li Y. The importance of engineering physiological functionality into microbes. Trend Biotechnol 2009;27(12):664-72.

[49] Zhou J, Zhu JY, Luo X, Leu S-Y, Wu X, Gleisner R, et al. Bioconversion of beetlekilled lodgepole pine using SPORL: process scale-up design, lignin coproduct, and high solids fermentation without detoxification. Ind Eng Chem Res 2013;52:16057-65.

[50] Öhgren K, Bura R, Lesnicki G, Saddler J, Zacchi G. A comparison between simultaneous saccharification and fermentation and separate hydrolysis and fermentation using steam-pretreated corn stover. Process Biochem 2007;42:834-9.

[51] Varga E, Klinke HB, Réczey K, Thomsen AB. High solid simultaneous saccharification and fermentation of wet oxidized corn stover to ethanol. Biotechnol Bioeng 2004;88(5):567-74.

[52] Hoyer K, Galbe M, Zacchi G. Influence of fiber degradation and concentration of fermentable sugars on simultaneous saccharification and fermentation of high-solids spruce slurry to ethanol. Biotechnol Biofuels 2013;6:145. 